\title{
Child Marriages: The Role of Twitter on the Child Marriages Problem in Turkey*
}

\author{
Çocuk Evlilikleri: Türkiye'de Twitter'ın Çocuk \\ Evlilikleri Sorunu Üzerindeki Rolü
}

Dr. Öğr. Ü. Esra Bayhantopçu**

\begin{abstract}
Child marriage is one of the major human rights problems in the world. Media is one of the most important tools to deal with this problem. This study intends to analyze the current portrayal of the child marriage problem on Twitter and examine the role of social media on this problem in Turkey. The presentation of the child marriage problem on Twitter is analyzed by examining the Twitter posts of 14 different accounts from the representatives of 4 different groups (5 newspapers, 3 government agencies 3 women's rights defenders, 3 NGOs working on children) for 5 different child marriage cases that occurred in Turkey. The sample is determined by using the purposive sampling method. Van Dijk's (1983) critical content and discourse analysis method is used for data analysis. 684 tweets for each case in the sample, shared on the day the cases happened and the following 8 days, were analyzed. According to the findings, the problem of child marriage in Turkey is not represented adequately on Twitter and the problem is not highlighted by the relevant groups. Despite the potential of social media to make the problem more visible, it has been observed that Twitter is not being used effectively to eliminate the child marriage problem in Turkey.
\end{abstract}

Keywords: Child Marriages, Social Media, Twitter, Gender, Media Analysis, Women's Studies.

* $\quad$ Bu makale, TÜBİTAK 2214-B bursu ile desteklenmiş, Galatasaray Üniversitesi Medya ve İletişim Çalışmaları ile Panthéon Sorbonne Paris 1 Üniversitesi Siyaset Bilimi çift diploma doktora programında, 2017 yılında sunulan doktora tezinden üretilmiştir. Kısa özeti, 2019 yılında ABD Uluslararası Sanat, Eğitim ve Sosyal Bilimler Konferansı - ICAES'de sunulmuştur.

** İstinye Üniversitesi İstanbul, Halkla İlişkiler ve Reklamcılık Bölümü, İletişim Fakültesi. ORCID: 0000-0001-6680-8414

Başvuru: 27.09.2021

Kabul: 11.11.2021

DOI: $10.21798 /$ kadem.2022.57
This work is licensed under the Creative Commons Attribution 4.0 International License.

Cite this article as: Bayhantopçu, E. (2021). Child Marriages: The Role of Twitter on the Child Marriages Problem in Turkey, Kadem Kadın Araştırmaları Dergisi, Cilt 7, Sayı 2: 191-218. 
Öz

Çocuk evlilikleri, insan haklarına ilişkin dünyamızın önemli sorunlarındandır. Medya ise bu sorunla mücadele etmenin en önemli araçlarından biridir. Bu çalışma, Twitter'daki çocuk evlilik sorununun ele alınış biçimini analiz etmeyi ve sosyal medyanın Türkiye'deki çocuk evlilikleri sorunu üzerindeki rolünü incelemeyi amaçlamaktadır. Bu kapsamda, çocuk evlilikleri sorununun Twitter'da temsil edilişini incelemek amacıyla amaca yönelik örneklem yöntemi kullanılarak, konuyla ilgili 4 farklı gruptan 14 farklı grup temsilcisinin ( 5 en çok satan gazete, 3 hükümet yetkilisi, 3 kadın hakları savunucusu, 3 çocuklarla ilgili çalışan STK), Türkiye'de meydana gelen 5 farklı çocuk evliliği vakası hakkındaki tweetleri incelenmiştir. Veri analiz yöntemi olarak Van Dijk’in (1983) kritik içerik ve söylem analizi yöntemi kullanılmıştır. Örneklemdeki vakaların gerçekleştiği gün ve takip eden 8 gün boyunda paylaşlan, vakalarla ilgili 684 tweet analiz edilmiştir. Elde edilen verilere göre, çocuk evlilikleri sorunu Twitter'da yeterince temsil edilmemekte ve konu ilgili gruplarca öne çıkarılmamaktadır. Sosyal medyanın sorunu daha görünür hale getirme potansiyeline rağmen, çocuk evlilikleri sorunuyla mücadele etmek için Twitter'dan etkin bir şekilde yararlanılmadığı görülmüştür.

Anahtar Kelimeler: Çocuk Evlilikleri, Sosyal Medya, Twitter, Toplumsal Cinsiyet, Medya Analizi, Kadın Çalışmaları.

\section{Genişletilmiş Özet}

\section{Amaç}

Çocuk evlilikleri, insan haklarına ilişkin önemli toplumsal sorunlardandır. Medya ise bu sorunla mücadele etmenin en önemli araçlarından biridir. Özellikle hızla dönüşen dünyada sosyal medya gündelik yaşamların vazgeçilmez bir unsuru haline gelmiştir. Günümüzde; sahip olduğu hız, çok fazla kişiye anında ulaşma kapasitesi ve gündem oluşturma gücü gibi sebeplerle sosyal medyanın toplumsal sorunları görünür kılmada etkili bir araç olarak kullanılıp kullanılmayacağı önemli bir nokta olarak öne çıkmaktadır. Bu çalışma, önemli bir toplumsal sorun olan çocuk evlilikleri probleminin Twitter'da ele alınış biçimini analiz etmeyi ve sosyal medyanın Türkiye'deki çocuk evlilikleri sorunu üzerindeki rolünü incelemeyi amaçlamaktadır.

Çalışma uygulamaya yönelik bir araştırmadır. Araştırma kapsamında öncelikle çocuk evlilikleri ve sosyal medyanın gelişimine yönelik literatür taraması yapılmıştır. Daha sonra, çocuk evliliklerinin Twitter'da ne şekilde temsil edildiğini ve Twitter'ın bir sosyal medya aracı olarak sorunun çözümü için bir araç olarak kullanılıp kullanılmadığını görmek 
amacıyla; amaca yönelik örneklem kullanılarak, sorunun çözüme ulaştırılmasında en çok etki sahibi olabilecek grupları temsilen 14 hesap belirlenmiştir. Bu gruplar şu şekildedir; 'gazeteler (5 en yüksek tirajlı gazete), devlet temsilcileri (3 ilgili bakanlık), çocuklarla ilgili çalışan Sivil Toplum Kuruluşları (STK'lar) (3 farklı STK), kadın hakları savunucuları (3 farklı kadın hakları savunucusu)'. Daha sonra yine amaca yönelik örneklem kullanılarak 2014-2015 yılları arasında Türkiye'de önem arz eden çocuk evliliklerine ilişkin 5 örnek olay belirlenmiştir. Bu vakalardan ilki, Siirt'de 12 yaşında evlendirilen, 13 yaşında çocuk sahibi olan 14 yaşında ise öldürülen Kader Ertan vakasıdır. İkinci örnek olay, 13 yaşında doğum yapmak için hastaneye giden bir çocuğun, doktor tarafından yasal mercilere bildirilmesi sonucu açılan davada çocuk evliliklerine ilişkin verilen ilk resmi karara ilişkindir. Üçüncü örnek olay Türk Ceza Yasası'nın yasal olmayan evliliklerin cezalarına ilişkin maddesinin değiştirilmesine yönelik yasa tasarısına ilişkindir. Dördüncü örnek olay, elektrik borcunu ödeyemeyen bir babanın kızını bu sebeple 14 yaşında evlendirmesine ilişkin vakadır. Beşinci örnek olay ise, aile bütünlüğünü korumak amacıyla, 18 yaşın altında bir çocukla evlenmiş ve şu anda ceza evinde olan erkeklerin salınmasına ilişkin yasa tasarısı önerisi ile ilgilidir. Vakaların her birinin gerçekleştiği 1 haftalık periyod süresince ilgili olayın başladığı ilk gün baz alınarak, bu günü takip eden 8 gün boyunca, 14 hesap temsilcinin paylaştığı tüm Twitter mesajları incelenmiştir. Belirlenen tarihlerde toplamda 9.182 mesaja ulaşılmış; örneklemdeki olaylarla ilgili olan 684 tweet çalışma kapsamında detaylı bir şekilde analiz edilmiştir. Veri analizinde Van Dijk’in kritik içerik ve söylem analizi yöntemi (1983) temel alınmıştır; bununla birlikte Günseli Bayraktutan ve diğerlerinin (2013) Van Dijk'in söylem analizini Twitter mesajlarına uyarlayarak geliştirdikleri söylem analizi metodu kullanılmıştır. Bu çerçevede; kişi/hesap bilgisi, atılan mesaj sayısı, kelime/cümle kullanımları, sosyal medya aracının yardımcı fonksiyonlarının kullanımları, şekil/fotoğraf kullanımları gibi kriterler analiz edilmiştir.

\section{Bulgular}

Çoğunlukla, güncel haberleri takip etmek, haberlere yorum yapmak ve politik konularda tartışmalara katılmak için kullanılan Twitter, haber amaçlı kullanımının ön plana çıkması ve mesajların anında pek çok kişiye ulaşabilme özelliği sayesinde toplumsal farkındalık yaratmanın önemli araçlarından biridir. Araştırma sonuçlarına göre, çocuk evlilikleri sorununun çözümünde etkili olacak grupların başında gelen gazeteler, devlet temsilcileri, ilgili STK'lar ve kadın hakları savunucularının Twitter'ın hızlı dolaşım ve çok kişiye ulaşma özelliklerini çok sık kullanmadığı ortaya çıkmıştır. 
Örneklemdeki tweetlerin \%67'si gazeteler, \%15’i kadın hakları savunucuları, \%15’i STK'lar, \%3’ü ise devlet temsilcileri tarafından atılmıştır. İlgili gruplar tarafından, mesajların hızlı bir şekilde diğer ilgili gruplara iletilmesi ya da konunun toplumun gündemine taşınmasını mümkün kılan Twitter'ın gündem oluşturma, 'mention' ve ‘hashtag' özelliklerinin çok fazla kullanılmadığı, bu nedenle mesajların dolaşım oranının çok düşük olduğu ortaya çıkmıştır.

Paylaşımlar söylemsel olarak analiz edildiğinde, tweetleri şu şekilde sinıflandırmak mümkündür: 'Duyuru amaçlı tweetler', 'Güncel haber paylaşma amaçlı tweetler', 'Farkındalık yaratma amaçlı tweetler', 'Aktivizmi teşvik eden tweeetler' ve 'İlgili otoriteleri eleştiren tweetler'.

Örneklem içinde çoğunlukla haber hakkında bilgi vermeye ya da duyuru yapmaya yönelik paylaşımlar bulunmaktadır. Özellikle gazetelerin, çocuk evlilikleri haberlerini cinayet ya da üzücü hayat hikâyeleri olarak aktardığı görülmüştür. STK ve kadın hakları savunucularının daha çok farkındalık yaratma ve bu konudaki aktivizmi teşvik etme amaçlı paylaşımlarda bulunduğu; bununla birlikte kadın hakları savunucularının paylaşımlarının çoğunun ilgili otoritelerin konuya duyarsızlığını suçlayacağı ifadeler taşıdığı görülmüştür.

Aktivizm amaçlı gönderilen paylaşımlar dışında, örneklemdeki hiç bir paylaşım sorunun çözümü için toplumun desteğini almaya yönelik değildir. Tweetlerde, sorununun sebeplerine yönelik bilgilendirmenin olmadığı, herhangi bir çözüm önerisi sunulmadığı görülmüştür. Sadece bir STK’nın konuyla ilgili farkındalık yaratmak için çocuk evliliği yaşayan iki kadının düşüncelerini aktardığı ve konuyla ilgili farkındalık yaratmaya çalıştığı görülmüştür. Kelime kullanımlarına bakıldığında, gazetelerin durumu daha çok normalleştiren 'çocuk gelin', 'çocuk evliliği', 'erken evlilik', bazı haberlerde ise 'çocuk istismarı' gibi ifadelerle aktardığı; STK ve kadın hakları savunucularının ise, konunun ciddiyetini daha çok açı̆̆a çıkaran 'pedofili', 'suç', 'tecavüz' gibi kelimeleri tercih ettiği görülmüştür. Sonuç olarak çalışma kapsamında; çocuk yaşta evlilik sorunuyla mücadele etmede Twitter'ın etkin bir araç olarak kullanılmadığı ortaya çıkmıştır.

\section{Sinırlılıklar}

Araştırmanın 2014-2015 yılları arasında gerçekleşmiş amaca uygun yöntemle belirlenmiş çocuk evliliklerine ilişkin olayları kapsaması araştırmanın sınırlılığını oluşturmaktadır. Sosyal medyanın toplumsal sorunlar üzerindeki rolünün ortaya çıkarılması için farklı toplumsal sorunların farklı sosyal medya araçlarında ne şekilde yer aldığını analiz eden daha fazla araştırmaya ihtiyaç vardır. 


\section{Öneriler}

Yasa ve yönetmeliklerin caydırıcı hale getirilmesi, ilgili mevzuatların birbiriyle uyumlu bir şekilde düzenlenmesi, ekonomik yetersizliklerin giderilmesi, özellikle kız çocuklarının eğitim olanaklarının arttırılması, konuyla ilgili toplumsal farkındalığın arttırılması gibi toplumda cinsiyet eşitliğinin sağlanmasına hizmet edecek ve aynı zamanda çocuk evliliklerini önleyecek temel önlemlerin yanı sıra, sorunun çözümü için Medya, Devlet, STK'lar ve diğer ilgili aktörler birlikte çalışmalı ve sorunu gündeme taşımalıdır. Bu noktada; gerek sahip olduğu hız gerek pek çok kişiye ulaşarak, etkileşim yaratma gücü açısından sosyal medya araçlarının kullanılması ve bu yolla toplumda farkındalık yaratılması önem taşımaktadır. İlgili gruplar, konuyu gerek attıkları mesaj sayısını gerekse mesajların dolaşım oranını arttırarak gündemde tutmalıdır. Bununla birlikte ilgili otoriteler, var olan söylem tarzlarını değiştirerek, sorunu normalleştiren genel geçer kelimeler yerine, sorununun önemini ortaya çıkaran ve yapıcı çözümler getiren bir dil kullanımını tercih edebilir. Buna ilaveten, ilgili gruplar ortaklıklar kurmalı ve yeni projeler gerçekleştirmeli, bunun içinse sosyal medyanın etkileşim yaratma özelliğinden yararlanılmalıdır. Bununla birlikte, akademik çalışmalar çerçevesinde, sorunun başka örnek vakalar ve temsilcileri de içine alacak şekilde araştırılması önem arz etmektedir.

\section{Özgün Değer}

Literatürde kadın ve çocuk hakları ile Twitter'ın toplumsal sorunlar üzerindeki rolüne ilişkin çalışmalar bulunmakla birlikte, çocuk yaşta evlilik sorununun Twitter'da temsilini içerik ve söylem analizi yöntemleri ile inceleyen araştırma sayısı kısıtlıdır. Ek olarak; birden fazla çocuk yaşta evlilik vakasının tek bir araştırmada incelenmesi ve sadece gazetelerin değil konuyla ilgili diğer grupların da dahil olduğu geniş bir örnekleminin olması, çalışmanın ayırt edici özelliklerindendir. Bu nedenle çalışmanın konuya ilişkin genel çerçevede bir tablo çizmesinin yapılacak diğer benzer akademik çalışmalara referans oluşturacağı düşünülmektedir. 


\section{Introduction}

"Child or early marriage is the union, whether or not official, of two persons, at least one of whom is under eighteen years of age" (UNFPA, 2014: 1). Child marriage is a global problem that cuts across religions, cultures and ethnicities. Marriage at an early age has several negative impacts on girls. They are neither physically nor emotionally ready to become wives or mothers (Flying Broom, 2012: 20). Girls forced into child marriage are deprived of being a child and its opportunities. Even though they are still children, they are defined by social customs as wives and mothers. Girl children who are forced to marriage end up taking many responsibilities even though they are not ready to do so neither physically nor mentally. Besides, they are usually deprived of education and employment rights. Apart from the negative impacts of child marriage on girls themselves, this problem also raises lots of problems for children in general, for families and the society as a whole (Mathur, Greene and Malhotra, 2003: 1). Therefore, the issue should be handled as a social problem.

Child marriages, especially for girl children, is a worldwide problem. According to the latest UNICEF Report (2014: 74) more than 700 million women worldwide were married before their eighteenth birthday. This figure constitutes $10 \%$ of the world's population. 250 million women were married or entered into union before their fifteenth birthday. Child marriages among girls is most common in South Asia and sub-Saharan Africa. South Asia has 42\% of all child marriages worldwide. One third of global child marriages take place in India. Niger has the highest rate of child marriages in the world, while Bangladesh has the highest rate of marriages involving girls under age fifteen. According to the Marriage Modeling Research of The United Nations (UN), child marriages rate among all marriages is approximately $9.6 \%$ in Turkey (UN, 2013). According to the Turkish Statistical Institute (TURKSTAT, 2020), among the 487,270 women who got married in Turkey in 2019, 13,014 were girls between ages sixteen and seventeen. And also, the child marriage rate 
was $2.7 \%$ in Turkey. On the other hand, according to the results ${ }^{1}$ of Hacettepe University's TDHS (Turkey Demographic and Health Survey) of 2018 (TDHS, 2019: 46), of women aged between twenty-five to forty-nine, 39\% marry by age twenty, $21 \%$ marry by age eighteen and $4 \%$ marry before they are fifteen.

There are many reasons for child marriages such as economic insufficiency, religion, traditional beliefs, honor, low levels of education and community pressure. There are also many ways to fight this problem. Strict national laws are among the most important ways. Articles governing the legal marriage age vary from country to country. All the countries in the world have legislation for the minimum marriage age, apart from Saudi Arabia, the United Arab Emirates, Gambia, the Holy See, Palau and Sudan. According to the UN 2011 Report, in 2010, the minimum legal marriage age for women without parental consent or approval by a pertinent authority was eighteen years or higher in 158 countries. In twenty-nine countries the minimum legal marriage age for women was below eighteen. In 146 countries, girls younger than eighteen could marry with parental consent or approval by a pertinent authority and, in 52 of these countries, girls under fifteen could marry with parental consent (UN, 2011: 1). The legal marriage age is eighteen for both men and women without exception in some countries such as France, Greece, Norway, Denmark, the Russian Federation, Sweden, Switzerland, and the United Kingdom. On the other hand, even though the legal age is determined as eighteen in countries such as Italy, Germany and Netherlands, these countries can make exceptions for people to marry at sixteen. While the legal marriage age is eighteen in the United States of America, in some states girls may get married as early as thirteen with the consent of their parents (Cornell University, 2014). In Turkey, the minimum legal marriage age for girls and boys without parental consent is seventeen but they may get married legally at age sixteen with parental consent. In Afghanistan

1 "The Hacettepe University survey is fielded between August-September 2018. Interviews were completed with 13,982 households and 7,345 women in 15-49 age group in 754 clusters" (TDHS, 2019: xiii). 
and Andorra, girls can marry at the age of sixteen according to the national laws.

The national laws of some other countries define the minimum age for marriage differently for girls and boys. For instance, in Niger, the minimum legal marriage age is fifteen for girls and eighteen for boys. In Bolivia, girls are permitted to marry at fourteen and boys at sixteen. The legal age of marriage for girls and boys are thirteen and fifteen respectively in Iran (UN, 2013). Such laws give rise to girls and boys under the age of eighteen to get married much more easily. In Bangladesh and India, the legal marriage age is eighteen for girls and twenty-one for boys but the highest child marriage rates in the world are seen in these countries. Similarly, in Brazil, even though the legal marriage age is twenty-one both for boys and girls, the percentage of those marrying before they are eighteen is $36 \%$ (UNICEF, 2014). As the numbers indicate, although the minimum legal marriage age without parental consent is eighteen or higher, child marriage rates are quite high in these countries. Based on these data, it may be claimed that although national legislations are of great importance, they are not enough to eliminate the problem.

The second important tool in tackling the problem is through international agreements. There are several international agreements that define children as people who are under the age of eighteen and establish some precaution for eliminating child marriages such as The Convention on the Rights of the Child (OHCHR, 1979), The Universal Declaration of Human Rights (UN, 1948) and the Convention on the Elimination of All Forms of Discrimination Against Women (OHCHR, 1979). While all of these international agreements determine that the legal marriage age should be eighteen for both girls and boys, not all countries in the world are party to them. Apart from national and international laws and agreements, media (especially social media) can be operative in creating public awareness. This study intends to analyze the role of social media in creating public awareness in Turkey on the child marriage problem. 


\section{Literature Review}

Social media is a new public sphere of our contemporary world. Hence, there is an important debate in the literature on social media (Castells, 2003; Hall, 2001; Kellner, 2004; Morozov, 2012; Shoemaker and Reese, 2014; Timisi, 2003). Particularly, its potential on social change has been discussed. The Internet, which is one of the fastest spreading communication tools, adds millions of new Internet users to the world's communication network each year. It enables users to get information easily and quickly about the events happening in different parts of the world. The Internet also has made it possible for people to access all levels of information and interact with news through commenting. As the Internet removes borders, it becomes necessary to put forward the features of this technology by emphasizing its potential in terms of participation and democracy. Moreover, it is important to evaluate the impact of social media platforms on social problems.

According to Shoemaker and Reese (2014: 134) the development of media organizastions on the Internet platform has extended the $20^{\text {th }}$ century media's core purposes and changed the way in which people interact with media content. Receivers of this new media content can now be its producers and senders as well. Online media changes the previous receivers into potential reporters. These online reporters can redescribe the world as they have access to different sources to gather information and different ways to process, present, and deliver it. They offer more extensive and diverse content compared to conventional media producer.

According to Jim Hall (2001: 53) this interactive structure, which offers more opportunities to users, reduces the amount of control that the news producer has. Unlike the older control system, which filters the news and sets the agenda, control is now being shared with the consumer. This is what makes social media unique compared to other media forms. As a communication channel, it still delivers news to the consumers. However, the control of this channel 
is increasingly removed from the hands of local politicians and big media corporations.

On the other hand, Hermida (2010: 4) claims that through filtering and selecting what news and tweets to publish, the gatekeeper role is maintained and enforced in social media. By this way, journalists adjust existing news rules when they determine if a specific tweet is newsworthy. At this point, it may be asserted that Kurt Lewin's Gatekeeping Theory (1947), which claims that information is filtered by the media before it reaches the public, and McCombs and Shaw' Agenda-Setting Theory (1972), which asserts that the prioritization of the news are set by the media, can also be applied to mainstream newspapers' posts on social media.

Therefore, it is essential to evaluate the potential of this new media form in terms of democratic participation and the rights of disadvantaged people. Information society theorist Manuel Castells (2003: 138) believes that the network society will encourage the emergence of a new type of social movement through the Internet that has a potential to contribute to the expansion of democratic participation. Also, he mentions that this new type of social movement which facilitates the collective action of values and social institutions in the twentieth century will take place much more easily and reach wider audiences through the Internet, which also makes individualized forms of collective action possible.

Timisi (2003) also argues that new technologies provide opportunities to individuals to acquire more information about political issues. She emphasizes that the Internet is at the center of democratic debates due to its feature of technological interaction. She states that, first, the Internet enables users to gain access to knowledge very easily and that it is faster than the traditional communication channels. Second, contrary to other communication tools, the Internet is not under the dominance of any authority. Governments, commercial powers, or other political authorities have no complete dominance over the Internet. The main reason behind this is that the Internet does not have a physical structure 
and it is not confined to a specific time and location (Timisi, 2003: 193-194).

Critical theorist Douglas Kellner (2004) underlines the democratic potential of the Internet as well. Kellner (2004: 715-735) indicates that information technologies have become very important in the new techno-capitalist society, as creating alternative information networks constitutes the main element of information politics and a democratic media. In the age of the Internet, anyone who has a computer and a modem can participate in public discussions. Many individuals, whose voices were not heard in the public discussions through the traditional media tools have, in this new era, regained their power to participate in the democratic dialogue.

Conversely, Evgeny Morozov (2012) takes a suspicious stance towards the Internet and claims that new media opportunities can be easily transformed into surveillance tools that serve dominant regimes rather than the opposing parties. Similarly, Zuboff (2014) in her work on surveillance capitalism states that under this system, the Internet is used to undermine autonomy and to erode democracy. She (2019: 24) argues that "people rushed to the Internet expecting empowerment and the democratization of knowledge, however surveillance capitalism didn't make it possible." However, despite this non-democratic outlook, digital spaces still offer opportunities for democratization. It may be asserted that online media constitute a discursive system in which social issues are enacted through textual discourse (Albert and Salam, 2013: 6). They give individuals an opportunity to express themselves and create new discursive spaces.

People use the Internet for sharing ideas, activities, international developments, and news as well as for discussing political issues. The Internet gives an opportunity to people to make their voices heard globally (Consalvo, 2011: 112). Social media is of great importance in this regard. There are several definitions of and frameworks for social media. In general, it can be defined as; "a group of Internetbased applications that build on the ideological and technological foundations of Web 2.0, and that allow the creation and exchange of 
User Generated Content” (Kaplan and Haenlein, 2010: 61). Different forms of social media exist, including social networking sites such as Facebook, content communities such as YouTube and micro-blogging sites such as Twitter. Social networking sites enable their users to connect with other people by creating personal profiles that provide information through audio-visual content and textual content allowing friends or other people to have access to these profiles and interact with each other (Kaplan and Haenlein, 2010: 61-63).

One of these social networking platforms, Twitter, is defined as a powerful and appealing communication platform which gives people a chance to express their ideas. Twitter entries (tweets) are limited to 280 characters. They can be made public and therefore open to a large audience. People can access other people's entries if their accounts are public. The entries can be shared through mobile phones, PCs, websites and desktop programs and they can be distributed in real time (O'Reilly and Milstein, 2009: 7). Reaching out to other people and sharing information become very easy with the help of Twitter. Unlike Facebook or LinkedIn, where members need to approve social connections, anyone can follow anyone on Twitter, unless the owner of the account makes it private (Rouse, 2015).

According to Alexa (2016), a company that provides commercial web traffic data and analytics, Twitter is the ninth most popular web site in the world. Twitter is also one of the most important social media networking applications in Turkey. According to the Digital in 2016 Report prepared by 'We Are Social' digital marketing agency, by January 2016 the population of Turkey was 79.14 million. 46.28 million people were active Internet users, and 42 million people were active social media users. The number of active social media users in the total population was 53\%. The annual growth in the number of active social media users was $5 \%$. The average daily use of social media via any device was two hours and thirty-two minutes, and $77 \%$ of the users used the Internet every day. According to the report, Twitter was the fourth most active social platform with $17 \%$ in 
2015 in Turkey ${ }^{2}$ (Wearesocial, 2016). According to the latest report of Monitera, a social media monitoring agency, there were 9.6 million Twitter users in 2015 in Turkey. 6.2 million of these users were active users. While $53 \%$ of the Twitter users were female, $47 \%$ of them were male (Webrazzi, 2016). The high active usage rate can be interpreted as an indication that Twitter has a significant power in terms of facilitating the spread of news fast and easy. Twitter is mostly used to share news, to get information about international developments and political issues, to discuss political issues and to comment on news. In this regard, it is important to discuss whether this new discoursive space has the power to generate public discussion, and thus motivate change, with regards to certain social problems.

\section{Methodology}

This study aims to analyze how the child marriage problem is presented on Twitter in Turkey by examining the tweets of some important actors. It seeks to find out the current portrayal of the issue on Twitter and examine whether social media contributes to its visibility in the public sphere.

The study adopts a qualitative approach which enables distinctive kinds of evidence and a more detailed evaluation of social phenomena. Moreover, it makes it possible to explore influences that are too complex or delicate to be captured through quantitative methodology (Boyce and Neale, 2006: 38-41). In order to evaluate the discourses of different social actors, four different groups who have the highest potential to raise awareness on the issue are determined and the important and well-known representatives of these groups are included in the sample. The tweets they posted during the related cases are examined. The purposive sampling method is used to determine these groups. The examined groups are constituted of five representatives from the top five rating national newspapers, three government agencies, three women's rights defenders 
and three NGOs working on this field. Their tweets are evaluated for five cases of either child marriage or related issues that occurred in 2014 and 2015 in Turkey. Purposive sampling is also used to determine these cases, as it makes it possible to focus on significant cases that played a key role in the recent history of child marriage in Turkey (Riffe, Lacy and Fico; 2005: 100). The first case is the death of Kader Erten who was forced to marry when she was twelve years old in Siirt, a city in eastern Turkey. She had a baby when she was thirteen years old and was killed at her fourteen. The second case is significant as it prompted the first court decision in Turkey about child marriages. A girl who was forced to marry at thirteen went to a hospital to give birth to her third child. The doctor realized that she was under eighteen years and reported it to the official authorities. The ensuing legal case resulted in the acquittal of the defendants (her husband and her father) upon the the girl's statement. The third case is about a proposal to change the articles in the Turkish Criminal Law that regulate the penalties regarding illegal marriages. The fourth case is a news story about a girl whose father forced her to marriage in order to be able to pay for electricity. The fifth case is about a proposed bill to the Turkish Parliament. This bill, claiming to protect the unity of the family, would enable the release of incarcerated men who married underage girls. The tweets of selected actors (14 different representatives) are analyzed for each case. For each of the cases, the first day of the incidents are taken as the starting point and the tweets posted in the following eight days are scanned for each account. The tweets are recorded in pdf format using the Twitter interface. The Twitter interfaces for four cases were registered on August 2016. The Twitter interfaces for the fifth case were registered on December 2016. The accounts were accessed retrospectively.

TeunVan Dijk (1983)'s critical content and discourse analysis method is used for analyzing the data. The discourse analysis model of Günseli Bayraktutan et al. (2013), which is adapted from Van Dijk's discourse analysis to Twitter interfaces, was also used. The Twitter Discourse Analysis Model of Bayrakturan et al. (2013) 
discusses tweets in terms of macro and microstructure. The criteria of person/account information, other information and web page criteria are examined under macro thematic structure. State description, background information, contextual information (schematic structure); active-passive sentence structure, simple or complex sentence structures (syntactic analysis); causative, functional and referential relationship (regional harmony); metaphor, meaning, connotation (word choice); images, persuasive information (rhetoric) are the criteria which are defined as microstructure (Bayraktutan et al., 2013: 186). Word choices, the frequency of posts, photographs, hashtags and mention numbers are also analyzed. 9,182 tweets were reached during the determined research period. 684 of these tweets, which are related to child marriage, children and women, are analyzed. Although there are many studies in the literature on women's rights and the role of Twitter on social problems, this study is of importance since there is a little amount of research that examines the presentation of the child marriage problem on Twitter through content and discourse analysis. In addition, the examination of more than one child marriage case, as well as conducting research with a large sample including not only newspapers but also other relevant groups, are the distinguishing features of this study.

\section{Findings}

New social media forms like Twitter ease the spreading of news and information from official and unofficial sources. They also enable users to reach a large variety of news sources by creating interaction between the news. These features of Twitter are of importance in terms of attracting people's attention to social problems. Child marriage problem is one of the important social problems of Turkey. This study examines 684 tweets that reflect the problem. 
Figure 1. Tweet Rates by Cases

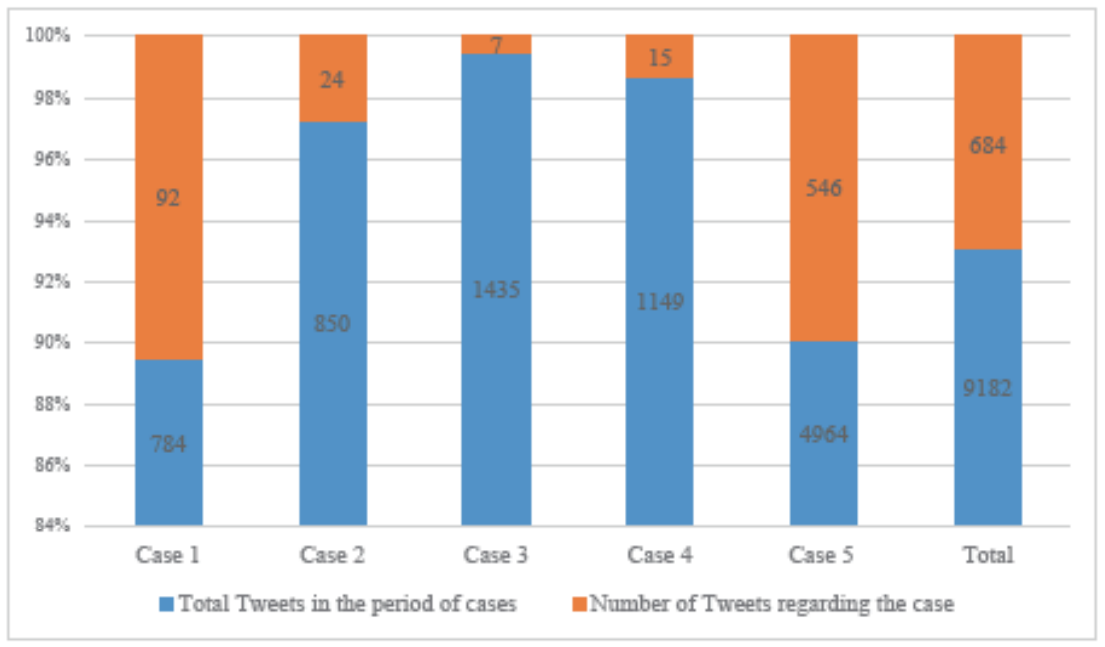

As illustrated in the graphic above, a total of 9,182 tweets are posted by the groups in the sample during the research period. 684 of these tweets are related to the problem of child marriages.

$67 \%$ of these tweets were posted by newspapers, $15 \%$ were posted by women's rights defenders, $15 \%$ by NGOs and $3 \%$ by government agencies. While 138 of the tweets were related with the first four cases, the remaining 546 were posted for Case 5, which is also related to political issues as will be discussed below.

Alfred Hermida (2010: 2-5) regards micro-blogging as an awareness system, where people instantly communicate with each other, share current news and their thoughts and discuss events. It is thus one of the new forms of collective intelligence. Since many people are connected to each other, one message can reach out to many receivers. Moreover, the circulation of messages makes them more visible. O'Reilly and Milstein (2009: 47) claim that most people interact with others in their networks who defend different political ideologies. By this way, they can affect other people's point of view. Re-tweeting (reposting a tweet that was shared by another account and therefore highlighting its message) is an important medium for the circulation 
of tweets. A mention is used in a tweet with the symbol '@', to address a specific user. The @ sign is a useful strategy for relating one tweet to another (Honeycutt and Herring, 2009: 1-3). It also enables communication between actors (e.g., between government agencies and citizens) and crates the opportunity to develop solutions for problems. "Hashtags are keywords to weave tweets into a conversation thread or connect them to a general topic. They are also permanent, searchable and public" (Rouse, 2015). These features enable users to follow important topics. Through them, messages are able to reach more people and can stay on the agenda. In some cases, the visibility of a case on social media triggers coverage and discussion on traditional media.

\section{Figure 2. Mention, Retweet, Hashtag Rates}

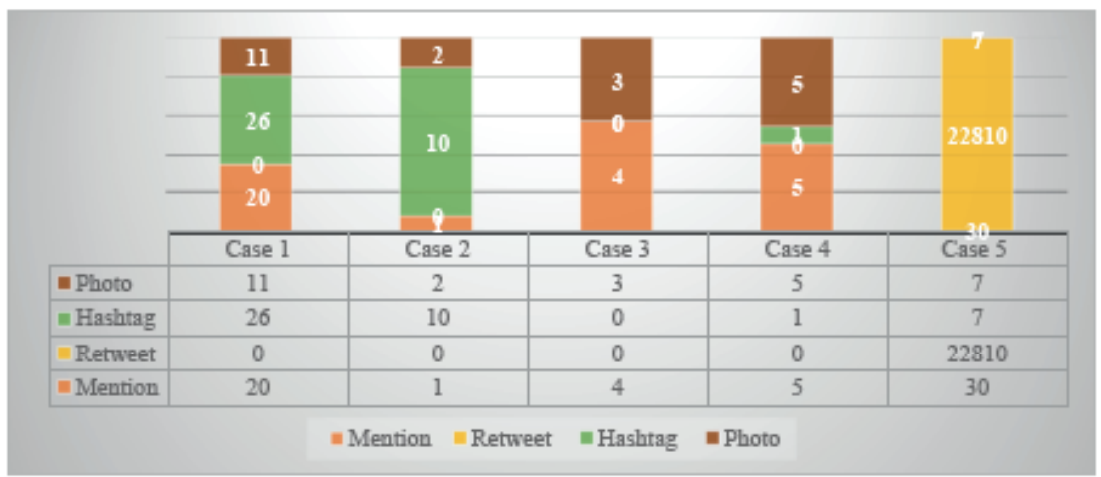

The research has found out that the circulation rate of tweets on child marriage is very low except for Case 5. For Cases 1, 2, 3 and 4 , some specific hashtags were used in $29 \%$ of the posts in the total. Mentions were used in $23 \%$ of all posts. $16 \%$ of the posts included photographs. ${ }^{3}$ As for Case 5; hashtags and photos were used in 1\% of the posts and mentions were used in $5.5 \%$ of the posts. On the other hand, posts were retweeted 22,810 times. If the visibility of the cases would only depend on the circulation of the posts, the visibility of Case 5 would be low however retweet rate is very high for

3 Since the number of tweets for the fifth case is very high, the sample is unbalanced. For this reason, it is preferred to provide the ratios by cases. 
Case 5, while there are no retweeted posts in the rest of the sample. This finding can be explained by the political dimension of the case. Since the proposed law would be a step towards normalizing child marriages, it would have a more serious impact on society. Therefore, it is possible that this case attracted more public attention.

Twitter enables the dissemination of news. Many users share and discuss news articles. In this regard, tweets can be used as a source of information and news-gathering by reporters (Morgan, Shariq and Lampe, 2013: 2). The tweet rates of newspapers in the sample are examined in this regard. Of the 8,545 tweets that were posted by the five examined newspapers during the research period, 460 were about child marriages. Although these newspapers were followed by a large number of accounts, the accounts they followed were few. They did not repost the other accounts' tweets in the sample, either. These data show that the newspapers did not use Twitter as a news source by gathering information from other users. The number of tweets posted about the cases were few. Only for the fifth case, more than one tweet was shared by the newspapers.

As for tweets by NGOs, they show that even if they are specialized in child marriages and issues related with children, these NGOs did not use Twitter frequently. The number of tweets posted by women's rights defenders on the issue were few in number as well. Even though all the women's rights defenders taking part in the sample posted a large number of tweets during the research period; among all tweets posted, the rate of those related to child marriage was $25 \%$.

When the tweets are analyzed discursively, it is possible to group them under five headings: tweets for making an announcement, tweets for sharing current news, tweets for creating awareness, tweets for promoting activism, tweets for criticizing related authorities.

All of the newspapers in the sample share tweets with the aim of sharing news. Government agencies share tweets with the aim of sharing news, however they share tweets mostly with the aim of making an announcement about their projects. 
Table 1. Tweets for Sharing Current News

\begin{tabular}{|c|l|l|l|}
\hline No & Account & Date & Tweet \\
\hline 1 & Newspapers & $01,16,2014$ & $\begin{array}{l}\text { Death that shook Turkey! An inves- } \\
\text { tigation was launched for Kader } \\
\text { married at 12 years of age and } \\
\text { found shot dead in her house'. }\end{array}$ \\
\hline 2 & Government & $01,14,2014$ & $\begin{array}{l}\text { As @ailebakanligi (The Minis- } \\
\text { try of Family) we registered the } \\
\text { case of Kader Erten who lost her } \\
\text { life in Siirt. http://www.aa.com. } \\
\text { tr/tr/s/273898--bakanlik-kader- } \\
\text { in-davasina-mudahil-oldu... }\end{array}$ \\
\hline
\end{tabular}

For instance, one of the tweets shared by the newspapers is shown at Table 1 (No.1). The headline highlights the issue as a case of murder, not child marriage. The exclamation mark implies that the incident (death) is shocking and unbelievable which is a sign of tacit criticism. It was stated that the child was married off at age 12 (arranged marriage). Similarly, government agencies shared information to show their sensibility about the issue (No.2).

In this respect, tendencies of the government agencies and the newspapers are similar. Like the newspapers, the number of tweets from the government agencies in the sample was small. There were only two tweets from the government agencies regarding child marriages. These tweets were posted by the Ministry of Family and Social Policies. While the Ministry was followed by 78.3K users, it followed fifty-eight accounts. The Ministry representatives rarely used Twitter features such as retweet, hashtag and mention. They did not reply to posts that mentioned their account. Observing these data, and within the scope of this research, it may be asserted that the Ministry used Twitter as a platform for announcing its activities and did not prefer to interact with stakeholders. When examined discursively, the newspapers used in their Twitter account the same headlines they used in printed issues. They did not choose to use a different discourse.

4 All the tweets on the tables have been translated from Turkish to English. 
NGOs and women's rights defenders also tweeted to share news; however, their tweets were mostly intended for creating awareness and promoting activism. Women's rights defenders also shared tweets that criticize related authorities. They used some denunciatory statements about government agencies, parents and the media. There are only two tweets about the life stories of women who were married at an early age. Two of the accounts did not communicate with their followers. They did not interact with other related actors either. Only one NGO interacted with its followers and used Twitter effectively by deploying mentions and hashtags.

\section{Table 2. Tweets for Creating Awareness and Promoting} Activism

\begin{tabular}{|c|l|l|l|}
\hline No & Account & Date & Tweet \\
\hline 3 & NGO & $\begin{array}{l}01,12, \\
2014\end{array}$ & $\begin{array}{l}\text { WHY do we call them \#CHILDBRIDES } \\
\text { when they r raped, sold for money, human } \\
\text { trafficking, forced marriages, tortured, } \\
\text { abused and finally killed? }\end{array}$ \\
\hline 4 & NGO & $\begin{array}{l}01,12, \\
2014\end{array}$ & $\begin{array}{l}\text { \#WeStartaWarAgainstPedophilia \#WeStar- } \\
\text { taWarAgainstPederastic \#childbride \#tur- } \\
\text { key \#child \#KaderErten }\end{array}$ \\
\hline 5 & $\begin{array}{l}\text { Women's } \\
\text { Rights } \\
\text { Defenders }\end{array}$ & $\begin{array}{l}05,29, \\
2015\end{array}$ & $\begin{array}{l}\text { Girls are sacrificed to population policies by } \\
\text { being forced to marry and have babies. All } \\
\text { the political parties have to make a state- } \\
\text { ment immediately }\end{array}$ \\
\hline
\end{tabular}

For instance, Tweet number 3 was posted both in Turkish and English for creating awareness. The use of the term 'child bride' was criticized and highlighted thematically by providing the word 'child bride' in capital letters. It was stated in the same tweet that children were raped and used as sex workers under the name of 'child bride'. They asked the reader 'why do you call them as child bride?' The tone implies that society is also guilty. Tweets Number 4 and 5 can be classified under tweets for promoting activism and tweets for criticizing related authorities. For instance, Tweet Number 4 was 
posted both for creating awareness and promoting activism through hashtags. Tweet Number 5 can be given as an example of tweets for criticizing related authorities. In this tweet, posted by a women's rights defender, political authorities are accused.

On the other hand, the discourse in the tweets posted by women's rights defenders was different from other posts in the sample. Women's rights defenders' tweets were sent mostly for creating awareness. They did not just share information in their tweets, they also used remarkable words to raise awareness. In most of their tweets that are included in the sample, they criticized state authorities; on the other hand, they stated that they were open to cooperation and they called the political authorities to discuss the problem and find solutions. They sent messages to political authorities by using Twitter mentions; however, none of the politicians replied to their posts. Apart from these kinds of messages, they posted tweets which proposed solutions. Different from the other tweets in the sample, there were two tweets posted by women's rights defenders about the life stories of girls who were married at an early age, so that allow the audience to empathize with them.

\section{Conclusion}

This study aimed to analyze how the child marriage problem was presented on Twitter in Turkey by examining the Twitter posts of some important actors and studying the role of Twitter in terms of making the problem visible on the public sphere.

Twitter is an effective medium to deliver messages quickly to related actors. It gives people the opportunity to produce more content and share their opinions freely. Twitter is also an important medium to draw public attention to social problems and raise awareness. Despite this power of Twitter, the study has found out that the actors related to the child marriage issue did not use Twitter effectively in raising awareness. This includes not sharing a high number of posts, not using the hashtags, not using related photographs which evoke child marriages. To raise awareness about the issue is also 
possible by conveying stories about women who were married at an early age, choosing words that do not normalize the issue, and bringing the issue on the agenda. Therefore, it has been observed that the problem of child marriages was not brought on the agenda by these groups and the problem was not highlighted.

In the sample, $67 \%$ of tweets were posted by the newspapers, $15 \%$ by women's rights defenders, $15 \%$ by NGOs and $3 \%$ by government agencies. When the posts were analyzed discursively, it became possible to group them under five headings; 'tweets for making an announcement', 'tweets for sharing current news', 'tweets for creating awareness', 'tweets for promoting activism' and 'tweets for criticizing related authorities'. From the obtained data, it has been observed that all newspapers' tweets are for sharing news. Government agencies share tweets with the aim of making announcements. NGOs and women's rights defenders also share tweets for sharing news; however, their tweets are mostly posted for creating awareness and promoting activism. They also send tweets which criticize related authorities.

In many of the posts that were generated by the examined newspapers about child marriages, the news reports were presented as the news of murder or in a narrative structure which mostly focused on feelings of sadness and mercy towards the individuals in the stories. Besides, in many posts, words that normalized the issue were preferred. For instance, while the term 'child bride' was preferred in most of the posts, in some tweets, 'early marriage' and 'child abuse' were preferred. On the other hand, some NGOs and women's rights defenders referred to child marriage with such phrases as 'pedophile', 'criminal offence', 'rape', 'parents who sell their children', which highlighted the seriousness of the situation. Some of these words were emphasized using capital letters.

The newspapers followed a few user accounts on Twitter. Although it is not possible to make general statements for all Turkish newspapers, it may be asserted that the newspapers within the sample did not use Twitter as a news-gathering medium. Based on the 
number of posts shared, it may be claimed that the gatekeeper role of conventional media was maintained and enforced in social media. Tweets regarding child marriages were few in number, although social media usage is easier and quicker. From the number of tweets in this sample, it can be concluded that the newspapers did not put forward the issue on the agenda.

Tweets by government agencies were few in number compared to all the tweets that were posted during the research period. They shared tweets mostly for making announcements. They did not use mentions and hashtags. In this sense, within the confines of this study, it may be argued that the government agencies used Twitter only to make announcements. They did not prefer to interact with the public. They did not create awareness about the problem by using Twitter effectively.

Sharing a post that was intended for related actors is of importance to motivate these actors to find a solution to the problem. In the sample, the rate of these kind of tweets is low. Only NGOs and women's rights defenders shared this kind of tweets. Women's rights defenders used mentions to send messages to political authorities. They not only shared information in their tweets, but also shared tweets to raise awareness. It is also noteworthy that there were two tweets posted by women's rights defenders in the sample, which narrated the life stories of girls who were married at an early age. It is important to share the experiences of these girls and their point of views in terms of presenting real life stories to the public. With the help of these real stories, people can empathize with these girls and regard the issue as a humanity problem. However, in the sample, the number of such quotations is low.

When NGOs' posts in the sample are evaluated, it is seen that, even if their working field was child marriages and children, NGOs did not use social media frequently and effectively to make these problems more visible. Only one NGO in the sample used Twitter effectively. On the other hand, NGOs were the most important group revealing the seriousness of the issue by using a different discourse. 
Their tweets drew attention to the social aspect of these issues in terms of societal responsibility. Using striking words, they tried to encourage people to take part in solving the problem. Even though these calls may not reach the relevant groups, they are important in terms of creating public awareness. NGOs used hashtags frequently. Especially the hashtag 'Turkey' was used frequently in their tweets. By using this hashtag, they emphasized that this was a problem for the whole country. Unlike other tweets in the sample, when describing the problem of child marriages, they used words such as pedophile, criminal offence and rape, which manifest the seriousness of the issue. Moreover, one NGO in the sample posted some tweets multiple times, which is important in terms of making the issue more visible.

When the first four cases were examined, it was found out that Twitter was not used effectively and did not reveal the problem. However, awareness was higher when the issue had a critical political side as in Case 5. Unlike the other cases, a high number of tweets were posted in the period of Case 5 and this issue remained on the agenda. In such a case, the newspapers brought the issue on the agenda. It is seen that if the issue remains on the agenda for a long time, it becomes more visible. Twitter's high circulation capacity and speed can be helpful and Twitter can be used as an important medium to urge relevant authorities to create solutions and to raise awareness in the society. In this case, significant awareness was raised about the issue due to the active use of social media and the public reacted to the law proposal. As a result of these reactions, the law proposal was withdrawn by the government. At this point, it can be asserted that there may be a causal relationship between highlighting the problem on social media and developing constructive solutions for it. However, in this study, it is found out that while it is possible to make the child marriages issue more visible through Twitter, it was not brought on the agenda by the related actors to raise awareness. On the other hand, more research is required to determine the role of social media on social problems. 
In addition to the basic measures that will prevent child marriages, such as eliminating economic inadequacies, increasing educational opportunities, raising awareness, ensuring the consistency of legislations, applying penalties and ensuring gender equality in society; states, NGOs and other related actors should assume responsibility and bring this problem on the agenda. They should make the issue widespread by using every media channel to create awareness. As seen in the study, especially newspapers are key actors to keep the issue on the agenda for a long time, raise awareness about the issue and mobilize the parties that will contribute to the solution of the problem. Instead of describing the issue with common words, which normalizes the problem, all actors related to this issue should highlight the importance of the problem by changing their discourses. Different statements such as 'pedophilia', 'forced marriage', 'children's rights', 'human rights', 'violence against children' should be used rather than normalizing expressions such as 'child brides', 'child mother', 'child marriages'. In this regard, it is also important to share information on the rights of children and the victims' life stories to create awareness. States, NGOs and other related actors should work together, build partnerships and develop new projects while at the same time taking advantage of social media.

\section{References}

Albert, S. Connie \& Salam, A.F. (2013). Critical Discourse Analysis: Toward Theories in SocialMedia. https://pdfs.semanticscholar.org/e249/c289b092cf2fae8e15d60521e0158415e65d.pdf.Accessed Date: 14.07.2013.

Alexa. (2016). "Twitter.com Traffic Statistics." https://www.alexa.com/siteinfo/ twitter.com. Accessed Date: 16.06.2016.

Bayraktutan, G., Binark, M., Aydemir. A., Çomu T., Doğu, B. \& İslamoğlu G. (2013). Sosyal Medya Ortamlarının Siyasal İletişim Uygulamaları Açısından İncelenmesi: Türkiye'de 2011 Genel Seçimleri’nde Facebook ve Twitter'in Siyasi Partiler ve Liderler Tarafindan Kullanılması (Proje No.111K263). Ankara: Bilig. 
Boyce, C. \& Neale, P. (2006). Conducting In-Depth Interviews: A Guide for Designing and Conducting In-Depth Interviews for Evaluation Input. Pathfinder International: Senior Evaluation Associate.

Castells, M. (2003). The Internet Galaxy: Reflections on the Internet, Business, and Society. USA: Oxford University Press.

Consalvo, M. (2011). Introduction to Part II. Robert Burnett. Mia Consalvo and Charles Ess (Ed.), Handbooks in Communication and Media The Handbook of Internet Studies, within (pp.111-115). UK: Blackwell Publishing Ltd.

Cornell University Law School. (2014). "Marriage Laws, Marriage Laws of the Fifty States”. https://www.law.cornell.edu/wex/table marriage. Accessed Date: 14.08.2014.

Flying Broom Report. (2012). "Early and Forced Marriage". https://www.girlsnotbrides.org/wpcontent/uploads/2012/12/Flying-Broom-Flying-News-publication-on-Early-and-Forced-Marriage.pdf. Accessed Date: 14.08.2013.

Hall, J. (2001). Online Journalism A Critical Primer. London: Pluto Press.

Hermida, A. (2010). "Twittering The News: The Emergence of Ambient Journalism”. Journalism Practice, 4 (3): 1-12.

Honeycutt, C. \& Susan C. H. (2009). "Beyond Microblogging: Conversation and Collaboration via Twitter". Forty-Second Hawai’i International Conference on System Sciences (HICSS-42). Los Alamitos, CA, IEEE Press. http:// citeseerx.ist.psu.edu/viewdoc/download?doi=10.1.1.692.9575\&rep=rep1\& type=pdf. Accessed Date: 14.07.2014.

Kaplan, M. A. \& Haenlein, M. (2010). "Users of The World, Unite! The Challenges and Opportunities of Social Media”. Business Horizons, 53, (1): 59-68.

Kellner, D. (2004). Tabandan Küreselleşme: Radikal Demokratik Bir Tenopolitikaya Doğru. Özbek, M. (Transl.). İstanbul: HilYayın.

Lewin, K. (1947). "Frontiers in Group Dynamics". Human Relations. Vol.1, 5-41. http://dx.doi.org/10.1177/001872674700100103. Accessed Date: 14.06.2014.

Mathur, S., Margaret, G. \& Malhotra, A. (2003). "Too Young to Wed". https:// www.icrw.org/sites/default/files/publications/Too-Young-to-Wed-theLives-Rights-and-Health-of-Young-Married-Girls.pdf. Accessed Date: 14.07.2014.

McCombs, M. E. \& Shaw, D. L. (1972). "The Agenda Setting Function of Mass Media”. The Public Opinion Quarterly, Vol. 36, (2): 176-187. UK: Oxford University Press. https://www.jstor.org/stable/i328158. 
Morgan, J., Shafiq, Z. M. \& Lampe, C. (2013). "Is News Sharing on Twitter Ideologically Biased?" 2013 Conference on Computer Supported Cooperative Work, 887-897. New York: ACM.

Morozov, E. (2012). The Net Delusion: How Not to Liberate the World. USA: Penguin.

OHCHR. (1979). "Convention on the Elimination of All Forms of Discrimination Against Women". https://www.ohchr.org/documents/professionalinterest/ cedaw.pdf. Accessed Date: 16.072014.

O'Reilly, T. \& Milstein, S. (2009). The Twitter Book. USA: O'Reilly Media.

Rouse, M. (2015). "Twitter". https://whatis.techtarget.com/definition/Twitter. Accessed Date: 16.08.2015.

Riffe, D., Lacy, S. \& Fico, F. G. (2005). Analyzing Media Messages Using Quantitative Content Analysis in Research. London: Lawrence Erlbaum Associates.

Shoemaker, J. P. \& Reese, S. D. (2014). Mediating the Message in The 21st Century A Media Sociology Perspective. NewYork: Routledge.

TDHS. (2019). Hacettepe University Institute of Population Studies. 2018 Turkey Demographic and Health Survey (TDHS-2018). Ankara: Elma Teknik Basım Matbaacılık.

Timisi, N. (2003). Yeni Iletisim Teknolojileri ve Demokrasi. Ankara: Dost Kitapevi.

TÜİK. (2020). Statistics on Child 2020. Ankara: Turkish Statistical Institute Printing Division.

UN. (1948). The Universal Declaration of Human Rights. https://www.un.org/en/ udhrbook/pdf/udhr_booklet_en_web.pdf. Accessed Date: 24.07.2014.

UN. (2011). Population Facts, World Marriage Patterns. https://www.un.org/en/ development/desa/population/publications/pdf/popfacts/PopFacts 2011-1. pdf. Accessed Date: 24.07.2014.

UN. (2013). World Marriage Data 2012. https://www.un.org/en/development/ desa/population/publications/dataset/marriage/wmd2012/MainFrame. html. Accessed Date: 24.07.2014.

UNFPA. (2014). Turkey Child Marriage 2014. https://www.unfpa.org/webdav/ site/eeca/shared/documents/publications/Turkey\%20English.pdf. Accessed Date: 24.07.2014.

UNICEF. (2014). Global Database. Child Marriage in the World Report Statistics. https://data.unicef.org/topic/child-protection/child-marriage/. Accessed Date: 24.07.2014.

Van Dijk, T. A. (1983). Discourse Analysis: Its Development and Application to the Structure of News. Journal of Communication, 33, (2): 20-43. 
Wearesocial. (2016). Digital in 2016 Report. https://wearesocial.com/uk/specialreports/digital-in-2016. Accessed Date: 16.07.2016.

Webrazzi. (2016). Twitter Users Reached to 9.6 Million in Turkey. https://webrazzi.com/2013/02/12/twitter-turkiye-istatistikleri-2013/. Accessed Date: 16.07.2016.

Zuboff, S. (2019). The Age of Surveillance Capitalism. The Fight for a Human Future at the New Frontier of Power. USA: PublicAffairs. 